\title{
Pengaruh Penerapan Model Pembelajaran Kooperatif Tipe Group Investigation terhadap Kemampuan Pemecahan Masalah Matematis ditinjau dari Motivasi Belajar Siswa Sekolah Menengah Pertama di Kampar
}

\author{
Seswira Yunita1), Lies Andriani'2), dan Ade Irma ${ }^{3)}$ \\ Program Studi Pendidikan Matematika, Universitas Islam Negeri Sultan Syarif Kasim Riau \\ Jl. H. R. Soebrantas KM. 15.5, Pekanbaru, Indonesia. 29283 \\ E-mail: seswiray@yahoo.com, lies.andriani@uin-suska.ac.id,ade.irma@uin-suska.ac.id
}

\begin{abstract}
ABSTRAK. Penelitian ini bertujuan untuk mengetahui pengaruh penerapan model pembelajaran kooperatif tipe group investigation terhadap kemampuan pemecahan masalah matematis ditinjau dari motivasi belajar siswa. Penelitian ini merupakan penelitian kuasi eksperimen dengan desain penelitian Two Group Posttest Only Design dan menggunakan teknik purposive sampling. Populasi dalam penelitian ini adalah seluruh siswa kelas VIII SMP di Kampar. Sedangkan sampel dalam penelitian ini adalah siswa kelas VIII 3 SMP IT Al-Ihsan Boarding School sebagai kelas eksperimen yang diberikan pembelajaran model group investigation (GI), dan VIII 2 sebagai kelas kontrol yang diberikan pembelajaran konvensional. Instrumen yang digunakan adalah angket motivasi belajar siswa dan tes kemampuan pemecahan masalah matematis siswa. Teknik analisis data yang digunakan dalam penelitian ini adalah uji-t dan anova dua arah (two way anova). Hasil penelitian menunjukkan bahwa: 1) Terdapat perbedaan kemampuan pemecahan masalah matematis antara siswa yang diajar menggunakan model pembelajaran kooperatif tipe group investigation dengan siswa yang diajar menggunakan pembelajaran konvensional. 2) Tidak terdapat interaksi antara model pembelajaran kooperatif tipe group investigation dan motivasi belajar terhadap kemampuan pemecahan masalah matematis siswa. Hasil penelitian tersebut memberikan kesimpulan bahwa model pembelajaran kooperatif tipe group investigation memberikan pengaruh terhadap kemampuan pemecahan masalah matematis. Akan tetapi jika ditinjau dari motivasi belajar, penerapan model pembelajaran kooperatif tipe group investigation tidak memberikan pengaruh terhadap kemampuan pemecahan masalah matematis siswa.
\end{abstract}

Kata kunci: Group Investigation, Pemecahan Masalah Matematis, Motivasi Belajar, Kuasi Eksperimen

\section{PENDAHULUAN}

Matematika merupakan ilmu dasar yang memegang peranan penting dalam kehidupan sehari-hari. Kemajuan ilmu pengetahuan dan teknologi yang dewasa ini tidak terlepas dari peran ilmu matematika itu sendiri. Sebagai ratu atau ibunya ilmu, matematika telah memberikan sumbangsih terhadap pengembangan ilmu pengetahuan dan penemuan-penemuan. Selain aspek penerapan, matematika juga tidak kalah penting dalam mempengaruhi penalaran seseorang. Pembelajaran matematika dapat membekali siswa dengan kemampuan berfikir logis, analitis, sistematis, kritis dan kreatif jika dihadapkan pada situasi masalah.

Menurut National Council of Teachers of Mathematics (NCTM) tahun 2000 (Noviarni, 2014) mengemukakan bahwa standar proses yang harus dimiliki dalam pembelajaran matematika merupakan kecakapan-kecakapan matematis yang terdiri dari beberapa aspek salah satunya pemecahan masalah. Sejalan dengan pendapat NCTM, Permendiknas No.58 Tahun 2014 merumuskan tujuan pembelajaran matematika pada pendidikan menengah yakni agar siswa memiliki kemampuan dalam pemecahan masalah. Pemecahan masalah menjadi salah satu target 
utama yang penting untuk dikembangkan dalam pembelajaran matematika, karena pembelajaran matematika tidak hanya dilakukan dengan mentransfer pengetahuan kepada siswa, tapi juga membantu siswa untuk membentuk pengetahuan mereka sendiri serta memberdayakan siswa untuk mampu memecahkan masalah yang dihadapi dalam pembelajaran.

Branca (Sumarno, 2010) mengemukakan bahwa pemecahan masalah matematis dijadikan sebagai proses inti dan utama dalam kurikulum matematika sehingga menjadi tujuan umum dalam pembelajaran matematika bahkan sebagai jantungnya matematika. Dengan mampu memecahkan masalah, siswa akan mampu berfikir kritis, kreatif dan mengembangkan kecakapan matematis lainnya. Jadi, jelaslah bahwa kemampuan pemecahan masalah merupakan salah satu kemampuan dasar yang harus dikuasai oleh siswa dan menjadi salah satu tujuan pembelajaran matematika. Mengingat pentingnya kemampuan pemecahan masalah matematis dalam pembelajaran matematika, maka kemampuan tersebut perlu ditingkatkan. Namun kenyataannya masih banyak siswa yang mengalami kesulitan dalam memahami permasalahan yang ada dalam soal matematika. Hasil studi PISA (Program for International Student Assesment) tahun 2015 menunjukkan bahwa Indonesia baru bisa menduduki peringkat 68 dari 72 negara.

Berdasarkan hasil tes kemampuan pemecahan masalah yang dilakukan penulis pada beberapa siswa kelas VIII SMP IT Al-Ihsan Boarding School, terlihat bahwa kemampuan pemecahan masalah siswa masih tergolong rendah. Ini ditunjukkan dari kesulitan siswa dalam menjawab soal berupa soal pemecahan masalah. Dari hasil tes yang telah dilakukan, hanya 13 dari 30 siswa yang mampu menjawab dengan benar dan sesuai dengan indikator pemecahan masalah, dengan persentase sebesar 43,3\%. Berdasarkan jumlah persentase tersebut, dapat ditarik suatu kesimpulan bahwa kemampuan pemecahan masalah matematis siswa masih tergolong rendah.

Hal ini juga didukung dari hasil wawancara penulis salah seorang guru matematika di SMP IT Al-Ihsan Boarding School, terlihat bahwa proses pembelajaran matematika di kelas masih terpusat pada guru. Guru menjadi satu-satunya pusat pembelajaran dalam setiap kegiatan di kelas sehingga dalam proses pembelajaran siswa menjadi kurang aktif karena hanya menerima apa yang dijelaskan oleh guru. Russefendi (1991) menyatakan bahwa sebagian besar matematika diberikan di sekolah melalui penjelasan konvensional dari guru sehingga membuat siswa menjadi pasif. Berkaitan dengan hal tersebut, maka diperlukan perbaikan dan pembaharuan dalam pembelajaran guna meningkatkan kemampuan pemecahan masalah matematis siswa dengan menciptakan kondisi belajar yang aktif, kreatif, efektif dan menyenangkan bagi siswa melalui model pembelajaran yang tepat dan sesuai dengan karakteristik siswa. Salah satu model pembelajaran yang dapat digunakan agar siswa terlibat secara aktif dalam belajar adalah model pembelajaran kooperatif.

Model pembelajaran kooperatif merupakan suatu model pengajaran dimana siswa belajar dalam kelompok-kelompok kecil yang memiliki tingkat kemampuan berbeda. Salah satu model pembelajaran kooperatif yang dapat memberikan kesempatan kepada siswa untuk bekerjasama dalam kelompok-kelompok kecil adalah pembelajaran kooperatif tipe group investigation. Menurut Hosnan (2014), model pembelajaran kooperatif tipe group investigation merupakan model pembelajaran yang memfasilitasi siswa untuk belajar dalam kelompok-kelompok kecil yang heterogen untuk mendiskusikan dan menyelesaikan suatu masalah yang ditugaskan guru kepada mereka. Selain itu, Ramon (2015) mengemukakan bahwa dalam proses belajar melalui group investigation, siswa akan belajar aktif dan memberi kesempatan kepada siswa untuk berpikir sendiri. Siswa dilibatkan sejak perencanaan baik dalam menentukan topik maupun cara untuk mempelajarinya melalui kegiatan investigasi. Siswa kemudian diarahkan kepada penemuan konsep atau prinsip dan diharapkan dapat menguasai konsep dengan baik, mampu merepresentasikan ideide mereka dengan baik serta mampu memiliki kemampuan pemecahan masalah yang baik pula. Dari penjelasan tersebut terlihat bahwa, pembelajaran dengan group investigation memberikan peluang bagi siswa untuk dapat menemukan sendiri konsep dan dapat memecahkan masalah yang mereka temukan. 
Selain model pembelajaran, karakteristik siswa juga mempengaruhi kualitas hasil pembelajaran. Salah satu karakteristik siswa yang mempengaruhi kualitas hasil pembelajaran, terutama kemampuan pemecahan masalah adalah motivasi belajar. Motivasi belajar adalah proses yang memberi semangat belajar, arah dan kegigihan perilaku. Syaiful (2008) mengemukakan bahwa di dalam proses pembelajaran motivasi sangat diperlukan, karena seseorang yang tidak mempunyai motivasi dalam belajar, tidak akan mungkin melakukan aktivitas belajar.

Berdasarkan latar belakang dan pentingnya masalah yang dikemukakan, maka konteks yang dikaji dalam penelitian ini adalah mengetahui: (1) ada atau tidaknya perbedaan kemampuan pemecahan masalah matematis siswa yang diajar dengan model pembelajaran kooperatif tipe group investigation dengan pembelajaran konvensional; (2) ada atau tidaknya interaksi antara model pembelajaran kooperatif tipe group investigation dan motivasi belajar terhadap kemampuan pemecahan masalah matematis siswa.

\section{TINJAUAN LITERATUR}

\section{Model Pembelajaran Kooperatif}

Model pembelajaran kooperatif merupakan suatu model pengajaran dimana siswa belajar dalam kelompok-kelompok kecil yang memiliki tingkat kemampuan berbeda. Selama menyelesaikan tugas kelompok, setiap anggota saling bekerjasama dan membantu untuk memahami suatu bahan pembelajaran. Adapun karakteristik pembelajaran kooperatif menurut Agus Suprijono (2009) adalah sebagai berikut:

1. Pembelajaran secara tim, Pembelajaran kooperatif adalah pembelajaran secara tim. Oleh karena itu, tim harus mampu membuat setiap siswa belajar dan harus saling membantu utnuk mencapai tujuan pembelajaran.

2. Didasarkan pada manajemen kooperatif, Fungsi perencanaan menunjukkan bahwa pembelajaran kooperatif memerlukan perencanaan yang matang agar proses pembelajaran berjalan secara efektif melalui langkah-langkah pembelajaran yang sudah ditentukan termasuk ketentuan-ketentuan yang sudah disepakati bersama. Karena itu perlu diatur tugas dan tanggung jawab setiap anggota kelompok.

3. Kemauan untuk bekerja sama, Keberhasilan pembelajaran kooperatif ditentukan oleh keberhasilan secara kelompok. Oleh sebab itu, prinsip kerjasama perlu ditekankan dalam proses pembelajaran kooperatif. Setiap anggota bukan saja harus diatur tugas dan tanggung jawab masing-masing, tetapi juga ditanamkan perlunya saling membantu. Misalkan, yang pintar perlu membantu yang kurang pintar.

4. Keterampilan bekerja sama, Kemauan untuk bekerja sama itu kemudian dipraktikkan melalui aktivitas dan kegiatan yang tergambarkan dalam keterampilan bekerja sama. Dengan demikian, siswa perlu didorong untuk mau dan sanggup berinteraksi dan berkomunikasi dengan anggota lain untuk memecahkan masalah bersama-sama.

\section{Model Pembelajaran Kooperatif Tipe Group Investigation}

Group Investigation merupakan model pembelajaran kooperatif yang berasal dari zamannya John Dewey. Model ini dikembangkan pertama kali oleh Thelan lalu diperluas dan dipertajam oleh Yael Sharan dari Universitas Tel Aviv. Menurut Hamdani (2011), model group investigation sering dipandang sebagai model yang paling kompleks dan paling sulit untuk dilaksanakan dalam pembelajaran kooperatif. Menurut Sharan, dkk (1980), group investigation adalah model pembelajaran yang melibatkan siswa sejak perencanaan, baik dalam menentukan topik maupun cara untuk mempelajarinya melalui investigasi.

Pembelajaran group investigation memberikan kesempatan kepada siswa untuk berpikir mandiri, aktif dalam mencari sumber-sumber belajar, menemukan sendiri konsep-konsep materi 
pelajaran melalui investigasi, berinteraksi dengan teman, dan bekerja sama di dalam kelompok, sedangkan guru hanya bertindak sebagai pembimbing, fasilitator, dan pemberi kritik yang membangun. Langkah-langkah pembelajaran model group investigation yang digunakan dalam penelitian ini adalah:

1. Kegiatan Awal

a. Guru mengucapkan salam pembuka, absensi dan mengkondisikan siswa dalam situasi belajar.

b. Guru menyampaikan tujuan pembelajaran.

c. Guru memberikan apersepsi dan motivasi dengan menghubungkan materi dengan kehidupan sehari-hari siswa.

d. Guru menyampaikan kepada siswa bahwa pembelajaran yang akan diterapkan menggunakan model pembelajaran group investigation.

e. Guru menjelaskah langkah-langkah model pembelajaran group investigation.

2. Kegiatan Inti

Eksplorasi

Tahap I: Seleksi Topik

a. Guru menyampaikan informasi singkat mengenai materi yang akan dijadikan topik dalam investigasi.

b. Siswa diorganisasikan ke dalam beberapa kelompok belajar secara heterogen, dimana masing-masing kelompok terdiri dari 5-6 orang.

c. Masing-masing kelompok memilih subtopik yang telah tersedia untuk diinvestigasi bersama kelompok.

d. Masing-masing ketua kelompok diminta untuk dapat membagikan tugas kepada anggota kelompok tentang apa yang akan diinvestigasi.

e. Guru membagikan LKS kepada setiap siswa yang berisikan masalah.

Tahap II: Perencanaan Kooperatif

Siswa merencanakan prosedur pembelajaran, tugas yang akan dipelajari serta melakukan pembagian tugas secara merata untuk setiap anggota kelompok.

Tahap III: Implementasi

Siswa melakukan proses penyelidikan dengan mengidentifikasi masalah yang ada pada LKS, mencari dan mengumpulkan informasi dari berbagai sumber.

Elaborasi

Tahap IV: Analisis dan sintesis

a. Siswa menganalisis data dan membuat kesimpulan dari LKS yang dikerjakan.

b. Guru memantau aktivitas siswa dan membimbing siswa yang mengalami kesulitan saat melakukan penyelidikan.

Tahap V: Presentasi hasil final

Guru meminta beberapa perwakilan kelompok untuk mempresentasikan hasil diskusinya dan memberi kesempatan kepada kelompok lain untuk menanggapi.

3. Kegiatan Akhir

Konfirmasi

Tahap IV: Evaluasi

a. Guru bersama siswa merumuskan kesimpulan tentang materi yang telah dipelajari.

b. Guru dan siswa melakukan refleksi terhadap kegiatan yang telah dilakukan dengan cara menanyakan pada siswa tentang materi yang belum dipahami.

c. Guru melakukan penilaian terhadap hasil kerja kelompok berupa latihan soal yang ada pada LKS.

d. Guru mengingatkan siswa untuk mempelajari materi selanjutnya.

e. Guru menutup pelajaran dengan mengucapkan salam. 


\section{Kemampuan Pemecahan Masalah Matematis}

Pemecahan masalah merupakan kompetensi dasar yang ditunjukkan siswa dalam memahami, memilih pendekatan dan strategi pemecahan, dan menyelesaikan model matematika untuk menyelesaikan masalah. Pemecahan masalah merupakan komponen yang sangat penting dalam matematika, karena tujuan belajar yang ingin dicapai dalam pemecahan masalah berkaitan dengan kehidupan sehari-hari.

Menurut Cooney (Heris Hendriana, 2014) mengemukakan bahwa kemampuan pemecahan masalah membantu siswa berpikir analitik dalam mengambil keputusan dalam kehidupan seharihari dan membantu meningkatkan kemampuan berpikir kritis dalam menghadapi situasi baru. Menurut Siswono (Ana Ari Wahyu Suci, 2012) terdapat beberapa faktor yang mempengaruhi kemampuan pemecahan masalah, yaitu: 1) Pengalaman awal, 2) Latar belakang matematika, 3) Keinginan dan motivasi, dan 4) Struktur masalah.

Tujuan atau kemampuan yang harus dicapai dalam pembelajaran, kemampuan pemecahan masalah dirinci dalam indikator berikut 1) Mengidentifikasi kecukupan data untuk pemecahan masalah. 2) Membuat model matematik dari situasi atau masalah sehari-hari dan menyelesaikannya. 3) Memilih dan menerapkan strategi untuk menyelesaikan masalah matematika atau di luar matematika. 4) Menjelasakan atau menginterprestasikan hasil sesuai permasalahan asal serta memeriksa kebenaran hasil atau jawaban. Dan, 5) Menerapkan matematika secara bermakna.

Berdasarkan uraian tersebut, maka indikator kemampuan pemecahan masalah matematis siswa yang digunakan pada penelitian ini adalah: 1) Memahami masalahnya. 2) Membuat rencana penyelesaian. 3) Melaksanakan rencana penyelesaian. Dan 4) Memeriksa kembali, mengecek hasilnya.

\section{Motivasi Belajar}

Motivasi belajar merupakan salah satu faktor yang mempengaruhi hasil belajar siswa. Menurut Mc. Donald (Oemar Hamalik, 2012) motivasi adalah suatu perubahan energi diri di dalam pribadi seseorang yang ditandai dengan timbulnya afektif dan reaksi untuk mencapai tujuan. Hakikat motivasi belajar adalah dorongan internal dan eksternal pada individu yang sedang belajar untuk mengadakan tingkah laku pada umumnya dengan beberapa indikator unsur yang mendukung.

Indikator motivasi belajar pada penelitian ini yang diambil dari pernyataan Hamzah (2010) adalah sebagai berikut: 1) Adanya hasrat dan keinginan berhasil. 2) Adanya dorongan dan kebutuhan dalam belajar. 3) Adanya harapan dan cita-cita masa depan. 4) Adanya penghargaan dalam belajar. Dan, 5) Adanya kegitan yang menarik dalam belajar. 6) Adanya lingkungan belajar yang kondusif sehingga memungkinkan seorang siswa belajar dengan baik.

Dalam melihat motivasi belajar siswa, peneliti memberikan angket yang berisi pertanyaanpertanyaan yang memuat indikator motivasi belajar yang peneliti gunakan sebelum sampel diberikan perlakuan.

\section{METODE}

Jenis penelitian yang digunakan dalam penelitian ini adalah kuasi eksperimen dengan desain two group posttest only design. Desain ini terdapat dua kelompok yang dipilih secara langsung. Kelompok pertama diberi perlakuan $(\mathrm{X})$ dan kelompok yang lain tidak. Kelompok yang diberi perlakuan disebut kelompok eksperimen dan kelompok yang tidak diberi perlakuan disebut kelompok kontrol. Endang (2012) secara rinci mengemukakan desain two group posttest only design pada tabel 1. 
Tabel 1. Rancangan Penelitian

\begin{tabular}{crc}
\hline Kelompok & Perlakuan & \multicolumn{2}{c}{ Posttest } \\
\hline $\mathrm{K}_{\mathrm{E}}$ & $\mathrm{X}$ & $\mathrm{O}_{2}$ \\
$\mathrm{~K}_{\mathrm{K}}$ & & $\mathrm{O}_{4}$ \\
\hline
\end{tabular}

Dengan $\mathrm{K}_{\mathrm{E}}$ adalah Kelompok Eksperimen, $\mathrm{K}_{\mathrm{K}}$ adalah Kelompok Kontrol, dan $\mathrm{X}$ adalah Pembelajaran dengan model pembelajaran kooperatif tipe group investigation, serta $\mathrm{O}_{2,4}$ adalah Posttest (Tes Akhir). Populasi dalam penelitian ini adalah seluruh siswa SMP Kelas VIII di Kampar tahun ajaran 2017/2018. Pengambilan sampel dilakukan dengan teknik purposive sampling. Sampel yang digunakan dalam penelitian ini terdiri dari kelas eksperimen dan kelas kontrol, dengan memilih dua kelas dari lima kelas yang ada di SMP IT Al-Ihsan Boarding School, dimana diperoleh kelas VIII.3 sebagai kelas eksperimen dan kelas VIII.2 sebagai kelas kontrol. Teknik ini digunakan setelah dilakukan uji Bartlet yang menyatakan kelima kelas adalah homogen dan setelah melakukan uji perbedaan rata-rata.

Penelitian ini terdiri dari 3 variabel yaitu variabel bebas, variabel terikat, dan variabel moderat. Variabel bebas dalam penelitian ini adalah model pembelajaran kooperatif tipe group investigation, variabel terikatnya adalah kemampuan pemecahan masalah matematis siswa, dan variabel moderatornya adalah motivasi belajar. Teknik yang digunakan untuk mengumpulkan data dalam penelitian ini adalah: (1) wawancara; (2) observasi; (3) dokumentasi; (4) tes; (5) angket.

Instrumen yang digunakan adalah angket untuk mengukur motivasi belajar siswa dan tes uraian untuk mengukur kemampuan pemecahan masalah matematis siswa. Agar kualitas instrumen angket dan tes baik dan dapat mengukur sikap/kemampuan yang diinginkan, maka sebelum instrumen diberikan pada kelas eksperimen dan kelas kontrol, terlebih dahulu membuat kisi-kisi angket dan tes sesuai dengan indikator, membuat butir pernyataan angket dan tes sesuai dengan kisi-kisi, melakukan validasi kepada validator dan melakukan uji coba angket dan tes.

Teknik analisis data yang digunakan dalam penelitian ini adalah uji-t dan anova dua arah (two way anova). Uji $\mathrm{t}$ digunakan untuk melihat perbedaan kemampuan pemecahan masalah matematis siswa antara siswa yang diajar menggunakan model pembelajaran kooperatif tipe group investigation dengan siswa yang diajar dengan pembelajaran konvensional. Sedangkan uji Anova dua arah digunakan untuk melihat interaksi antara model pembelajaran kooperatif tipe group investigation dan motivasi belajar terhadap kemampuan pemecahan masalah matematis siswa.

\section{HASIL}

Berdasarkan hasil analisis data yang peneliti lakukan diperoleh beberapa temuan. Hasil perhitungan kemampuan pemecahan masalah matematis diperoleh nilai rata-rata dari siswa kelas eksperimen sebesar 73,26 dan nilai rata-rata dari siswa kelas kontrol adalah 64,23. Data kemampuan pemecahan masalah pada kelas eksperimen dan kelas kontrol berdistribusi normal, terlihat pada tabel 2 berikut:

Tabel 2. Hasil Uji Normalitas

\begin{tabular}{llll}
\hline Kelas & $X_{\text {bitung }}^{2}$ & $X_{\text {tabel }}^{2}$ & Kriteria \\
\hline Eksperimen & 7,43 & 11,07 & Normal \\
Kontrol & 4,42 & 11,07 & Normal \\
\hline
\end{tabular}

Selain itu, dari data kemampuan pemecahan masalah matematis diperoleh $\mathrm{F}_{\text {hitung }}=1,31<\mathrm{F}_{\text {(tabel) }}=1,96$ untuk signifikasi 0,05 . Maka varians-varians adalah homogen. Soal kemampuan pemecahan masalah yang diberikan merupakan soal yang valid dan reliabel. Berdasarkan hasil uji coba reliabilitas butir tes secara keseluruhan diperoleh harga $r_{\text {bitung }}=0,97$, dengan menggunakan $\mathrm{dk}=25-2=23$ dan signifikan 5\%. Didapat $r_{\text {tabel }}=0,396$. Jadi, diperoleh 
perbandingan harga rhitung $=0,97>r_{\text {tabel }}=0,396$ maka instrumen penelitan tersebut reliable. Sedangkan hasil uji validitas dapat dilihat pada tabel 3 berikut:

Tabel 3. Uji Validitas Soal Kemampuan Pemecahan Masalah Matematis

\begin{tabular}{llllll}
\hline No & $\mathrm{r}_{\text {hitung }}$ & $\mathrm{t}_{\text {hitung }}$ & $\mathrm{t}_{\text {tabel }}$ & Keputusan & Keterangan \\
\hline 1 & 0,772 & 9,16 & 2,07 & Valid & Dapat Digunakan \\
2 & 0,527 & 3,49 & 2,07 & Valid & Dapat Digunakan \\
3 & 0,78 & 9,543 & 2,07 & Valid & Dapat Digunakan \\
4 & 0,606 & 4,6 & 2,07 & Valid & Dapat Digunakan \\
5 & 0,76 & 8,61 & 2,07 & Valid & Dapat Digunakan \\
6 & 0,546 & 3,73 & 2,07 & Valid & Dapat Digunakan \\
7 & 0,52 & 3,42 & 2,07 & Valid & Dapat Digunakan \\
\hline
\end{tabular}

Selanjutnya diperoleh bahwa $t_{\text {hitung }}=3,9$ dan $t_{\text {tabel }}=2,01$ pada taraf signifikan 5\%. Maka nilai $t_{\text {hitung }} \geq t_{\text {tabel }}$ yang berarti $\mathrm{H}_{\mathrm{a}}$ diterima dan $\mathrm{H}_{\mathrm{o}}$ ditolak. Jadi, dapat disimpulkan bahwa terdapat perbedaan kemampuan pemecahan masalah matematis siswa yang diajar dengan model pembelajaran kooperatif tipe group investigation dengan siswa yang diajar dengan pembelajaran konvensional. Jika dibandingkan, terlihat bahwa model pembelajaran kooperatif tipe group investigation lebih baik daripada pembelajaran konvensional terhadap kemampuan pemecahan masalah matematis siswa. Temuan yang kedua adalah dari hasil perhitungan ANOVA dua arah, diperoleh bahwa $\mathrm{F}_{\text {hitung }}=2,86$ dan $\mathrm{F}_{\text {tabel }}=3,2674$ pada taraf signifikan $5 \%$, maka nilai $\mathrm{F}_{\text {hitung }}<\mathrm{F}_{\text {tabel }}$ yang berarti $\mathrm{H}_{a}$ ditolak dan $\mathrm{H}_{0}$ diterima. Jadi, dapat disimpulkan bahwa tidak terdapat interaksi antara model pembelajaran kooperatif tipe Group Investigation dan motivasi belajar terhadap pemecahan masalah matematis siswa.

\section{PEMBAHASAN}

Penelitian ini bertujuan untuk melihat pengaruh penerapan model pembelajaran kooperatif tipe group investigation terhadap kemampuan pemecahan masalah matematis siswa ditinjau dari motivsi belajar siswa. Penerapan model pembelajaran kooperatif tipe group investigation dilakukan dalam rangka meningkatkan kemampuan pemecahan masalah matematis siswa yang menjadi kemampuan dasar dalam pembelajaran matematika. Berdasarkan hasil penelitian terlihat bahwa terdapat perbedaan kemampuan pemecahan masalah matematis siswa yang diajar dengan model pembelajaran kooperatif tipe group investigation dengan siswa yang diajar dengan pembelajaran konvensional. Hal ini berimplikasi bahwa penerapan model pembelajaran kooperatif tipe group investigation berpengaruh positif terhadap kemampuan pemecahan masalah matematis siswa.

Penggunaan model pembelajaran kooperatif tipe group investigation memberikan dampak positif terhadap hasil belajar siswa dikarenakan dalam model ini pembagian kelompok dilakukan secara heterogen sehingga siswa bisa membaur dengan teman-temannya. Siswa yang kurang pandai dapat bertanya kepada teman sekelompoknya mengenai materi yang belum dipahaminya. Sedangkan pada pembelajaran konvensioanal penyampaian materi sepenuhnya dilakukan oleh guru, sehingga siswa yang lebih pandai dapat dengan cepat memahami materi. Siswa yang kurang pandai cenderung diam dan malu bertanya mengenai materi yang belum dipahaminya tersebut.

Selain itu, hasil temuan lainnya diperoleh tidak adanya interaksi antara metode pembelajaran dan motivasi belajar siswa memberi arti bahwa kemampuan pemecahan masalah matematis siswa yang mempunyai motivasi belajar tinggi sama dengan kemampuan pemecahan masalah matematis siswa yang mempunyai motivasi belajar sedang, dan juga sama dengan kemampuan pemecahan masalah matematis siswa yang mempunyai motivasi belajar rendah, baik pada penggunaan model pembelajaran kooperatif tipe Group Investigation maupun pembelajaran 
konvensional. Jadi, meskipun diberi perlakuan metode pembelajaran yang berbeda, jika ditinjau dari motivasi belajar siswa hasilnya tidak mempengaruhi kemampuan pemecahan masalah matematis siswa. Hal ini disebabkan adanya variabel bebas lain yang tidak termasuk dalam penelitian ini yang memberikan pengaruh lebih besar terhadap kemampuan pemecahan masalah matematis siswa, di antaranya adalah faktor intelegensi, minat belajar, sikap belajar, aktivitas belajar, gaya belajar dan sebagainya.

Penelitian ini mempunyai keterbatasan, yakni sampel yang diambil tidak begitu luas dan hanya pada kelas VIII SMP IT Al-Ihsan Boarding School tahun ajaran 2017/2018. Sehingga agar hasil penelitian dapat digeneralisasikan dengan baik maka untuk selanjutnya ukuran sampel diperluas dengan menggunakan beberapa sekolah sebagai lokasi penelitian. Selain itu, dalam prakteknya model pembelajaran kooperatif tipe Group Investigation memerlukan waktu yang cukup lama agar langkah-langkah pembelajaran dapat berjalan dengan maksimal. Oleh karena itu, sebaiknya sebelum menerapkan model ini guru perlu memperhatikan materi yang cocok dengan waktu yang diperlukan.

\section{REFERENSI}

Badan Standar Nasional Pendidikan (BSNP). (2006) Model Penilaian Kelas. Jakarta: Depdiknas.

Hamalik, O. (2012). Psikologi Belajar \& Mengajar, Bandung: Sinar Baru Algensindo.

Hamdani. (2011). Strategi Belajar Mengajar. Bandung: CV Pustaka Setia.

Hendriana, H dan Soemarmo, U. (2014). Penilaian Pembelajaran Matematika, Bandung: PT. Refika Aditama.

Hosnan, M. (2014). Pendekatan Saintifik dan Kontekstual dalam Pembelajaran Abad 21, Bogor: Ghalia Indonesia.

Muhandaz, R. (2015). Pengaruh Model Pembelajaran Kooperatif Tipe Investigasi Kelompok terhadap Pemecahan Masalah Matematis Siswa Kelas VIII MTs Kota Padang, Suska Journal of Mathematics Education. Vol.1, No.1.

Noviarni. (2014). Perencanaan Pembelajaran Matematika dan Aplikasinya. Pekanbaru: Benteng Media.

Ruseffendi, E. E. (2003). Pengantar Kepada membantu Guru Mengembangkan Kompetensinya dalam Pengajaran Matematika untuk Meningkatkan CBSA. Bandung: Transito.

Sharan, dkk. (1984). Cooperative Learning in the Classroom: Research in Desegregated Schools. Hilsdale, NJ: Erlbaum.

Suci, A. A. W. dan Rosyidi, A. H. (2012) "Kemampuan Pemecahan Masalah Matematika Siswa pada Pembelajaran Problem Posing Berkelompok", Jurnal FMIP A Unesa. Vol.1, No.2.

Sumarno, U. (2006b). "Kemandirian Belajar: Apa, Mengapa dan Bagaimana Dikembangkan pada Peserta Didik" Paper Presented at Seminar of Mathematic Education in Department of Mathematics, Faculty of Mathematics and Science, State University of Yogyakarta. Makalah dimuat dalam Suryadi, D, Turmudi, Nurlaelah, E. (Editor). Kumpulan Makalah Proses Berpikir dan Disposisi Matematik dan Pembelajarannya. 2014. Jurusan Pendidikan matematika FMIPA UPI.

Suprijono, A. (2009). Cooperatif Learning, Teori \& Aplikasi P AIKEM. Yogyakarta: Pustaka Pelajar.

Uno, H. B. (2010). Teori Motivasi dan Pengukurannya, Jakarta: PT. Bumi Aksara. 